\title{
EU:n maatalousuudistuksen vaikutukset Suomen maitotiloilla
}

\author{
Leena Riepponen ${ }^{1)}$ ja Ellen Huan-Niemi ${ }^{2)}$ \\ ${ }^{1)}$ MTT Taloustutkimus, Luutnantintie 13,00410 Helsinki, leena.riepponen@mtt.fi \\ ${ }^{2)}$ MTT Taloustutkimus, Luutnantintie 13,00410 Helsinki, ellen.huan-niemi@mtt.fi
}

\section{Johdanto}

Maidontuotanto on tärkeä osa suomalaista maataloutta. Lähes puolet maataloustuotannon tuottajahintaisesta arvosta tulee maidontuotannosta. Suomessa tukien merkitys maataloudelle on keskeisempää kuin muualla Euroopassa, koska täällä tuotteiden tuotantokustannukset ovat muita EU-maita korkeammat epäedullisten luonnonolosuhteiden ja pienen tilakoon vuoksi.

EU:n maatalouspolitiikan pitkän aikavälin uudistuksesta päästiin ratkaisuun kesäkuussa 2003. Uudistuksen mukaan pääosa EU:n kokonaan rahoittamista maataloustuista (CAP-tuet) irrotetaan tuotannosta ja perustetaan uusi tuotannosta irrotettu tilatukijärjestelmä. Etelä-Suomen kansallisesta tuesta päästiin ratkaisuun EU:n komission kanssa lokakuussa 2003. Koska ratkaisun yksityiskohdat ovat vielä päättämättä, kansalliseen tukeen tulevia muutoksia ei ole otettu huomioon tässä tutkimuksessa.

Tämän tutkimuksen tarkoituksena oli selvittää, mitä vaikutuksia maatalouspolitiikan pitkän aikavälin uudistus aiheuttaa tilakokoaan kasvattavien suomalaisten maitotilojen maataloustuloon vuoteen 2010 mennessä. Laskelmat laadittiin maitotiloille, jotka 1) jatkavat maidontuotantoa, 2) siirtyvät kokonaan viljantuotantoon vuonna 2007 tai 3) lopettavat maataloustuotannon vuonna 2007, mutta pitävät pellot kesannolla. Laskelmissa oli mukana myös vaihtoehto 4, jossa tilakoko ei kasva, vaan peltoala ja eläinmäärä pysyvät vuoden 2000 tasolla.

\section{Aineisto ja menetelmät}

Tutkimus perustuu maatalouden kannattavuustutkimuksessa mukana olevien maitotilojen aineistoon. Aineistossa mukana olevat maitotilat ovat olleet kannattavuuskirjanpidossa yhtäjaksoisesti vuodesta 1990 vuoteen 2000. Maitotilaksi luetaan tila, joka EU:n FADN (Farm Accountancy Data Network) -järjestelmässä luokitellaan maidontuotantoon erikoistuneeksi tilaksi vuonna 2000. Luokittelu perustuu vakioituihin katteisiin (standard gross margin, SGM), jotka lasketaan suuralueittain kullekin viljelykasville ja kotieläimelle erikseen. Vakioitu kate saadaan, kun tuotoista vähennetään tietyt muuttuvat kustannukset. Kun kunkin kasvin ja eläimen vakioidulla katteella kerrotaan tilan kasvien pinta-alat ja eläinten lukumäärät, saadaan tilan vakioitu kokonaiskate. Tilan tuotantosuunta määräytyy kokonaiskatteen koostumuksen perusteella. Maitotilaksi määritellään tila, jolla lypsylehmien kokonaiskate on suurempi kuin 2/3 tilan vakioidusta kokonaiskatteesta. Näistä tiloista mukaan otettiin tilat, jotka myös vuonna 1990 olivat maitotalouteen erikoistuneita tiloja. Tällöin tuotantosuunta määritettiin kokonaistuoton koostumuksen perusteella. Maitotiloja olivat tilat, joilla koko nautakarjatuoton osuus kokonaistuotosta oli vähintään $80 \%$ ja nautakarjatuottoon sisältyvän maitotuoton osuus oli vähintään $50 \%$ kokonaistuotosta. Näin menetellen paneeliaineistoon saatiin yhteensä 202 maitotilaa.

Paneeliaineiston avulla oli tarkoitus ennustaa tilakoon kasvu sekä kustannusten ja tuotantomäärien muutokset. Suomi liittyi Euroopan unioniin vuonna 1995, jonka jälkeen maatalouden toimintaympäristö muuttui. Tällöin kansallisesta maatalouspolitiikasta siirryttiin EU:n yhteiseen maatalouspolitiikkaan. Tutkimuksessa mukana olleiden maitotilojen peltoala ja eläinmäärä kasvoivat hitaasti ennen EU-jäsenyyttä, mutta vuoden 1995 jälkeen alkoi voimakas tilakoon kasvu uuden investointitukijärjestelmän myötä. Näin ollen ennustemallin pohjaksi päätettiin ottaa vuodet 1995-2000. Kustannusten ja tilakoon kasvun ennustaminen vuosille 2001-2010 tehtiin käyttämällä regressioanalyysiä. Regressioanalyysi tehtiin koko tilaryhmälle, ei tilakohtaisesti. Kustannukset, myyntituotot ja tuet laskettiin vuoden 2000 hintatasossa. Kustannuksiin sisältyivät kaikki kustannuserät, jotka tarvitaan maataloustulon laskemiseksi eli muuttuvat kustannukset ja kiinteistä kustannuksista kaikki muut paitsi yrittäjäperheen palkka ja oman pääoman korko.

Maitotuotto ennustettiin vuosittaisen maitomäärän ja maidon hinnan perusteella. Vuotuisessa maitomäärässä otettiin huomioon myös lypsylehmien keskituotoksen nousu. Keskituotoksen kasvu määritettiin regressioanalyysillä, ja se perustui karjantarkkailussa mukana olevien lehmien keskituotoksen kasvuun vuosina 1995-2000. Muun nautakarjatuoton (liha) ja kasvinviljelytuoton ennustettiin kasvavan eläinmäärän ja peltoalan lisäyksen suhteella. Muu kotieläintuotto ja muu kuin kotieläin- 
tai kasvinviljelytuotto pidettiin vuoden 2000 tasolla. Näiden osuus kaikista myyntituotoista vuonna 2000 oli vajaat kolme prosenttia.

Tässä tutkimuksessa maidontuotantoa jatkavilla tiloilla keskimääräisen lehmämäärän ennakoitiin kasvavan 21 lehmästä 28 lehmään vuosina 2000-2010. Peltohehtaarien ennakoitiin kasvavan samana aikana keskimäärin 41 hehtaarista 56 hehtaariin. Vuotuisen maitotuotoksen lypsylehmää kohti ennakoitiin kasvavan 7600 kilosta 9100 kiloon. Jos tila lopettaa maidon tuotannon ja siirtyy viljantuotantoon, peltoalan kasvaa 41 hehtaarista 56 hehtaariin vuosina 2000-2010. Jos tila lopettaa maataloustuotannon, mutta pitää pellot kesannolla, peltoala kasvaa vuoteen 2007 mennessä 51 hehtaariin, minkä jälkeen tilakoko ei enää kasva.

\section{Maatalousuudistuksen ratkaisut}

Laskelmissa otettiin huomioon EU:n maatalousneuvoston kesäkuussa 2003 päätetyn maatalousuudistuksen ratkaisut maitotiloilla vuoteen 2010 asti. Uudistuksen mukaan pääosa nykyisistä CAP-tuista irrotetaan tuotannosta ja muodostetaan uusi tilatukijärjestelmä. Järjestelmä tulee voimaan vuonna 2005 tai viimeistään vuonna 2007. Tuotannosta irrotettu tuki maksetaan vuosien 2000-2002 CAP-tukien perusteella. Uudistuksen toteutustapa jäi osittain kunkin jäsenmaan valittavaksi. Kansallisesti voidaan esimerkiksi päättää, maksetaanko tilatuki alueittaisena tasatukena vai tilan vuosina 2000-2002 saamien tukien perusteella ja millä tavoin osa nautatuista säilytetään eläinpalkkioina. Koska Suomessa nämä valinnat ovat vielä tekemättä, tämän tutkimuksen laskelmissa oletettiin, että kaikki nykyiset CAP-tuet irrotetaan tuotannosta vuonna 2005 ja niitä maksetaan vuosien 2000-2002 perusteella osana uutta tilatukijärjestelmää. Tilakoon kasvaessa lisähehtaarien ei oletettu saavan näitä tukia.

Uudistuksen mukaan voin interventiohinta laskee asteittain 25 prosenttia vuoteen 2007 mennessä ja maitojauheen hinta laskee 15 prosenttia vuoteen 2006 mennessä. Näissä laskelmissa maidon hinnan oletettiin laskevan 20 prosenttia nykytasosta vuoteen 2007 mennessä. Hinnan alenemisen korvaukseksi tiloille maksetaan tilakohtaisiin maitokiintiöihin perustuvaa lypsylehmäpalkkiota. Tämän tutkimuksen laskelmissa lypsylehmäpalkkio maksetaan vuosina 2004-2007 tilakohtaisen kiintiön mukaan, mutta vuodesta 2007 alkaen lypsylehmäpalkkio irrotetaan tuotannosta ja yhdistetään maatilatukeen. Vuodesta 2007 alkaen tilatuen tukioikeus määräytyy tilalla 31.3.2007 olevan maitokiintiön perusteella. Vuoden 2007 jälkeen tilan saamat lisäkiintiöt eivät enää saa lypsylehmäpalkkiota.

Maatalousuudistuksen mukaan uuden tilatukijärjestelmän mukaisia tukia leikataan asteittain vuodesta 2005 alkaen. Vuonna 2005 alennus on kolme prosenttia ja viisi prosenttia vuodesta 2007 vuoteen 2012. Leikkauksen ulkopuolelle jäävät tilat, joilla uuden tilatukijärjestelmän mukaiset tuet ovat alle 5000 euroa.

\section{Siirtyminen viljan tuotantoon tai kesannointiin}

Tutkimuksessa tarkasteltiin myös sitä, mitä tapahtuu maitotilojen maataloustulolle, jos maidontuotantoa harjoittanut tila lopettaa maidontuotannon 1.4.2007 tai sen jälkeen ja siirtyy joko viljantuotantoon tai lopettaa maataloustuotannon mutta pitää pellot kesannolla. Viljantuotantovaihtoehdossa peltoala on kokonaan viljan tuotannossa. Viljan myyntituotto määritettiin sen mukaan, mitä se kannattavuuskirjanpidossa mukana olevilla viljatiloilla oli hehtaaria kohti vuonna 2000. Tilakohtainen viljan myyntituotto kasvaa samassa suhteessa kuin tilakoko. Vuosittaista satotason nousua ei laskelmissa otettu huomioon, vaan satotason oletettiin pysyvän vuoden 2000 tasolla. Viljatilan tuottoihin sisältyy myös muu tuotto, joka pidetään vuoden 2000 tasossa. Muu tuotto sisältää muun muassa konevuokratulot. Vuonna 2000 muun tuoton osuus kaikista myyntituotoista oli noin kaksi prosenttia. Viljantuotantoon siirtyvä tila saa uuteen tilatukijärjestelmään oikeutettavat tuotannosta irrotetut tuet sekä muut viljatilalle kuuluvat EU:n osarahoittamat tai kansalliset tuet. Viljan tuotantoon siirtyvä tila saa näin ollen myös 31.3.2007 tilan omistuksessa olevan maitokiintiön mukaisen lypsylehmäpalkkion osana tilatukea. Vuodesta 2007 alkaen viljan tuotantoon siirtyvien tilojen kustannukset määritettiin kirjanpitotiloilta laskettujen viljan tuotantokustannusten perusteella (Riepponen 2003).

Jos tila lopettaa maataloustuotannon mutta pitää pellot kesannolla, tilalla ei varsinaisesti ole myyntituottoja; ainoastaan laskelman lähtötilanteessa eli tilalla vuonna 2000 ollut muu tuotto säilytetään ennallaan. Tilan peltoala kasvaa vuoteen 2007 asti, jonka jälkeen tilakoko ei enää kasva. Kesannointiin siirtyvä tila saa vuodesta 2007 alkaen tilatukeen oikeuttavat tuet sekä LFA-tuen mutta ei ympäristötukea. Kustannukset määritettiin vuodesta 2007 alkaen MKL:n mallilaskelmien perusteella (ProAgria Maaseutukeskusten Liitto 2002). 


\section{Tulokset}

Tulokset esitetään keskiarvoina koko maan tasolla. Tuotantovaihtoehto 1 eli maidontuotantoa jatkavien tilojen tuloksista esitetään lyhyesti muutokset myyntituotoissa, tuissa, kustannuksissa ja maataloustulossa. Vaihtoehdoista 2, 3 ja 4 esitetään vain maataloustulo.

\section{Tuotot ja tuet}

Maidontuotantoa jatkavien tilojen tilakohtaiset myyntituotot kasvavat vuodesta 2000 vuoteen 2010 mennessä 32 prosenttia. Eläinyksikköä kohti lasketut myyntituotot alenevat jakson aikana kolme prosenttia (Kuva 1). Lehmää kohti laskettu maitotuotto alenee myös kolme prosenttia. Vaikka maidon hinta alenee, maitotuotossa ei tapahdu kovin suurta laskua, mikä johtuu ennakoidusta keskituotoksen noususta.

Ennustejakson aikana tilaa kohti laskettavien tukien määrä kasvaa 55 prosenttia. Tukiin sisältyy myös maidon tuotantotuki. Tukia kasvattaa erityisesti vuodesta 2004 alkaen maksettava lypsylehmäpalkkio, joka kompensoi osittain maidon hinnan laskua. Tuet eläinyksikköä kohti kasvavat vuoteen 2010 mennessä 14 prosenttia. Eläinyksikkökohtaiset tuet nousevat eniten vuodesta 2005 vuoteen 2006, jonka jälkeen ne pysyvät samalla tasolla.

\section{Kustannukset}

Maidontuotantoa jatkavilla tiloilla tilakoon kasvaessa myös kokonaiskustannukset kasvavat. Ennustejakson aikana tilakoon kasvaessa kokonaiskustannukset kasvavat 34 prosenttia vuodesta 2000 vuoteen 2010. Eläinyksikköä kohti lasketut kustannukset pysyvät lähes samoina jakson aikana. Kustannuserissä on kuitenkin eroja. Eläinyksikköä kohti lasketut ostorehu-, muut kotieläin-, lannoite- ja muut kasvinviljelykustannukset kasvavat 17 prosenttia jakson aikana, kun taas energia-, korjaus-, vakuutus- ja muut muuttuvat kustannukset alenevat kolme prosenttia. Kiinteisiin kustannuksiin kuuluvat poistot alenevat yhdeksän prosenttia eläinyksikköä kohti laskettuna. Vieraalle maksetut palkat, velkojen korot ja pellon vuokrat alenevat viisi prosenttia eläinyksikköä kohti laskettuna.

\section{Maataloustulo}

Maidontuotanto -vaihtoehdossa tilojen maataloustulo kasvaa lähes joka vuosi tilakoon kasvun myötä. Vuonna 2007 tilakohtainen maataloustulo laskee hiukan edellisestä vuodesta, mutta sen jälkeen se taas kasvaa, sillä maidon hinnan lasku päättyy vuoden 2007 jälkeen (Taulukko 1). Vuonna 2010 maataloustulo tilaa kohti on 15 prosenttia suurempi kuin vuonna 2005 ja 55 prosenttia suurempi kuin vuonna 2000. Eläinyksikköä kohti laskettu maataloustulo kasvaa vuodesta 2000 vuoteen 200613 prosenttia, ja vuonna 2007 se on viisi prosenttia alempi kuin edellisenä vuonna. Vuodesta 2008 alkaen eläinyksikkökohtainen maataloustulo alkaa hiukan nousta ollen vuonna 2010 samalla tasolla kuin vuosina 20042006.

Taulukko 1. Maatalousuudistuksen vaikutukset maitotilojen maataloustuloon.

\begin{tabular}{|c|c|c|c|c|c|c|}
\hline & \multicolumn{6}{|c|}{ Maataloustulo, $€ /$ tila } \\
\hline & 2005 & 2006 & 2007 & 2008 & 2009 & 2010 \\
\hline Lehmiä, kpl/tila & 24,7 & 25,4 & 26,1 & 26,8 & 27,5 & 28,3 \\
\hline Peltoa, ha/tila & 48,1 & 49,7 & 51,2 & 52,7 & 54,3 & 55,8 \\
\hline Maitotilojen jatkamisvaihtoehdot: & & & & & & \\
\hline 1) Maidontuotanto & 44800 & 46100 & 44900 & 47100 & 49300 & 51700 \\
\hline 2) Viljantuotanto, 2007 alkaen & & & 18300 & 18000 & 17700 & 17500 \\
\hline - osuus vaihtoehto 1:n maataloustulosta & & & $41 \%$ & $38 \%$ & $36 \%$ & $34 \%$ \\
\hline 3) Kesannointi, 2007 alkaen & & & 15800 & 15400 & 15100 & 14700 \\
\hline - osuus vaihtoehto 1:n maataloustulosta & & & $35 \%$ & $33 \%$ & $31 \%$ & $28 \%$ \\
\hline 4)Maidontuotanto, ei kasvua, 41 ha, 21 lehmää & 31700 & 30500 & 27600 & 27400 & 27100 & 26800 \\
\hline
\end{tabular}

Viljantuotantoon siirryttäessä tilakohtainen maataloustulo vuonna 2007 on 41 prosenttia maidontuotantoa jatkavien tilojen maataloustulosta. Seuraavina vuosina viljantuotannossa maataloustulon osuus maitotilojen maataloustulosta pienenee. 
Jos tila lopettaa maataloustuotannon ja pitää pellot kesannolla, sen maataloustulo on vuonna 2007 kolmannes maitotilojen maataloustulosta ja vuonna 2010 reilu neljännes maitotilojen maataloustulosta.

Jos tilakoko ei kasva, vuosien 2000-2010 aikana maataloustulo alenee 20 prosenttia. Tässä vaihtoehdossa otettiin huomioon ainoastaan maidon hinnan aleneminen, uuden tilatukijärjestelmän mukaiset tuet ja tukien leikkaus. Muut tuotot ja muut kuin uuteen tilatukijärjestelmään kuuluvat tuet sekä kustannukset säilyvät vuoden 2000 tasolla. Lypsylehmien tuotostasossa ei myöskään tapahdu kasvua.

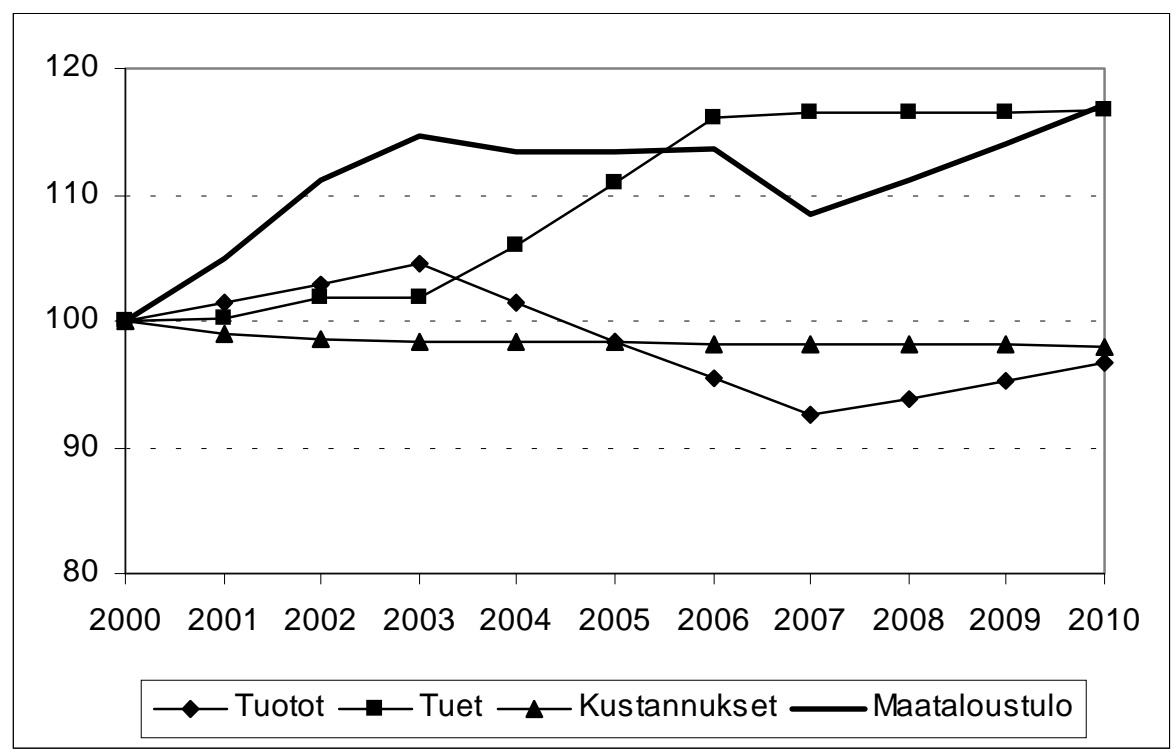

Kuva 1. Eläinyksikkökohtaisten tuottojen, tukien, kustannusten ja maataloustulon kehitys vuodesta 2000 vuoteen 2010 (vuosi 2000=100) maidontuotantoa jatkavilla tiloilla.

\section{Johtopäätökset}

Tukien merkitys maatalouden kannattavuudelle on paljon suurempi Suomessa kuin muissa EU-maissa maamme epäedullisten luonnonolosuhteiden vuoksi. Koska maidon tuotantokustannukset ovat Suomessa erittäin korkeat, tukien irrottaminen tuotannosta saattaisi johtaa maidontuotannon lopettamiseen ja siirtymiseen ehkä viljantuotantoon tai kesannointiin. Yksikkökustannuksia voidaan alentaa kasvattamalla tilakokoa, mutta toisaalta maidon hinnan aleneminen ja tukien irrottaminen tuotannosta vähentävät halukkuutta investoida. Vaikka tilakoon kasvattamishalukkuus tulevaisuudessa pienenisi, tuotantosuunnan muuttamista kokonaan kasvinviljelyyn ei ehkä koeta mielekkäänä, jos maitotila on vastikään investoinut voimakkaasti maidontuotantoon. Maidontuotantoa jatketaan tässä tapauksessa ehkä pienemmilläkin tuloilla ainakin lähivuosina.

Tutkimuksen mukaan tilakokoaan kasvattavilla maitotiloilla maatalousuudistus ei rohkaise viljelijöitä lopettamaan maidontuotantoa, jos vaihtoehtoisia tulolähteitä ei ole tarjolla. Maataloustulo tilaa kohti tulee kasvamaan vuodesta 2004 vuosikymmenen lopulle asti viidenneksen, jos tilakoko kasvaa ennakoidulla tavalla. Eläinyksikköä kohti laskettu maataloustulo pysyy melko samana vuodesta 2005 vuoteen 2010, tosin vuonna 2007 se alenee hiukan, mutta kääntyy sitten taas nousuun. Jos maitotilat siirtyisivät viljan tuotantoon tai lopettaisivat maatalouden kokonaan, tilakohtainen maataloustulo olisi noin kolmannes maidontuotantoa jatkavien tilojen maataloustulosta. Jos viljelijä ei löydä vaihtoehtoista työtä tilan ulkopuolelta, ei pelkällä viljantuotannolla tai kesannoinnilla tulla toimeen. Kansallisilla tuilla ja maidon myyntituloilla on kuitenkin suuri merkitys maitotilojen tuotannon kannattavuudelle.

\section{Kirjallisuus}

ProAgria Maaseutukeskusten Liitto 2002. Mallilaskelmia maataloudesta 2002. Tuotantokustannuslaskelmat. Maataloustuet 2001-2003. Maaseutukeskusten Liiton julkaisuja 985. Helsinki: ProAgria Maaseutukeskusten Liitto. 45 s. ISBN 951-808-106-9.

Riepponen, L. 2003. Maidon ja viljan tuotantokustannukset Suomen kirjanpitotiloilla vuosina 19982000. MTT:n julkaisuja 19. Helsinki: MTT. 32 s. ISBN 951-729-735-1. 